\title{
New Trends in the Study of Religion in Estonia: Contemplations in the Grey Zone between Religion and Science
}

\author{
Tõnno Jonuks
}

\begin{abstract}
Department of Folkloristics, Estonian Literary Musem; Center of Excellence in Estonian Studies tonno@folklore.ee
\end{abstract}

\begin{abstract}
The study of Estonian folk religion has traditionally been characterised by a relatively slight interest of academic scholars. Simultaneously, folk religion has been actively used in the creation of Estonian national identity. Such an old division has changed in the past fifteen years. Academic scholars have become more active in this field and concurrently a contemporary pagan movement has emerged as a new and influential participant in these studies. This national paganism has been presented not primarily as a religious movement but as cultural heritage. As a result, contemporary pagan views are partly accepted in scholarly works, thus creating a conceptually new understanding, in which religious arguments almost dominate over the classical academic ones. This paper criticises such an amorphous approach, which makes it difficult, if not impossible, to distinguish religious, national, and academic arguments and purposes.

Key words: contemporary paganism, critical methodology, Estonia, national identity, religious studies
\end{abstract}

Past religions have been of little interest to academic researchers in Estonia. This situation has considerably changed in the last decade and a completely new, conceptually different and influential approach has evolved recently. Hereinafter I will attempt, in the form of an essay, to give a brief overview of the study of past religions in Estonia (for more detailed research into the history of Estonian religious studies see Valk \& Kulmar 2015) and summarise some critical views about the contemporary tradition. Since this is not exclusively an analysis of academic research, many of the arguments below are based on popular scientific articles, TV series, newspaper articles, and personal conversations. Hence, an essay-like style, reflecting the author's personal impressions, has been chosen, and many of the arguments, whilst apparent in the research situation, are not referred to. 
Religion has been discussed for research purposes since the Enlightenment of the late 18th century in Estonia (Hupel 1774; Merkel 1798). Starting from the period of Romanticism in the 19th century, Estonian folk religion became a favourite topic for the young Estonian intelligentsia (e.g. Peterson 1822; Kreutzwald \& Neus 1854). Religion also became one of the cornerstones for national ideologists (e.g. Jakobson 1870; Reiman 1901; Luiga 1908) but academic researchers have traditionally stood clear of the theme. The historiography of the Estonian research on religion commonly starts at the end of the 19th century, together with the organised collection of folklore. However, the purposes of this campaign - to collect folk songs, stories, etc. - derived from the antiquarian nature of the romanticist era, which valued folklore as part of national identity (Herder 1773). The systematic study of Estonian religion did, indeed, begin in the first days of the newly established Republic of Estonia in the $1920 \mathrm{~s}$, when folklore collectors J. M. Eisen and J. Hurt started to publish the first summaries based on their collections (e.g. Eisen 1918, 1926). These publications, considered useless pursuant to the methodology used today, were soon followed by folklorist Oskar Loorits' research $(1934,1935)$, which in the 1920s-1930s defined the traditions for the studies of religion in Estonia for almost all of the following century. Here it is curious to note that religion was considered of interest in Estonia only by folklorists, to a lesser extent also by theologians, but historians and archaeologists dealt with much earthlier and more practical matters from the point of view of the young republic. Hence, archaeologists studied the beginning of the settlement in Estonia and the strongholds of the Late Iron Age as two of the most important topics for national identity (Lang 2006). Historians, however, drew on the broader frame of political and military history, and considered agrarian history and a focus on country folk to be of primary importance - again, important issues in the context of a new republic and national identity. Therefore, religion and other intangible objects of research remained the domain of folklorists. Other fields of research adopted the picture created on the basis of oral tradition without hesitation and from then onwards it became the norm that the religion in the past, even thousands of years ago, was studied based on the folklore of the 19 th and 20 th centuries. 
Alongside academic researchers there was another category of authors of a relatively diffuse background who, in the first decades of the 20th century, aimed to strengthen Estonian national identity and used religion for this purpose. It was often an ideal construction of past beliefs, based, on the one hand, on folklore collections, but even more so on the author's fantasy. This is how many of the colourful and national romantic writings about Estonian folk and prehistoric religion (e.g. Heraklides 1908) emerged, bashfully ignored by academic scholars.

One example of the use of prehistoric religion and its connection with the ideologies of that time was offered by Juhan Luiga (18731927), a medical doctor and a politician, and the later initiator of the pagan movement of the Taara religion, in an article entitled "Eesti muinasusk" (Estonian Ancient Religion) published in 1908:

Christianity was met with natural resistance in our country because in the format that it was brought from the Catholic Church to the world market in the 12th and 13th centuries, it could, it must have been, understandably disagreeable to the Finnish wise men as to every human being with healthy instincts.

Prehistoric religion was undoubtedly higher and nicer in many regards, based on the present view of the world, than the religion in the church of the time. Only then, when Christianity was changed pursuant to the spirit of the North, for example as in Protestantism, could it hope to be accepted naturally, could it hope for the decomposition of the Finnish people. But despite everything, Christianity won over the hearts of the Estonians only after their [collective] heart had been completely broken and their body was in fetters, i.e. in between the 17th and 18th centuries. (Luiga 1995 [1908]: 199)

The paragraph above shows eloquently the tendency that emerged already during the Enlightenment but was revived during the time of the national awakening at the end of the 19th century - the ancient religion was harmonious and noble and was destroyed with violence by the Catholic Church, which later on developed into accepted Lutheranism with a quality of "Nordic crispness" to it according to the rhetoric of the time. A critical view towards the Catholicism of the Middle Ages, or more generally "the German 
Church", was characteristic also of many academic scholars of the beginning of the 20th century (e.g. Moora 1924).

Such historical and ideological processes formed the background where a "grey zone" emerged in the late 19th and the early 20 th centuries, in which authors seemingly represented the scholarly approach, while the purpose of these studies was ideological - either to strengthen the national identity or to use history to legitimise ideological statements. There was nothing to be condemned in these writings per se - they completely served their purpose, i.e., to strengthen Estonian national identity and, by opposing the Baltic-German historians, to show the superiority and morality (according to Lutheran values) of the Estonian culture before the Nordic crusades in the 13 th century. However, the lack of academic studies into religion became a problem. This led to a situation in which little alternative existed to the genre of fantasy and thus primarily ideological books and papers became main influencers of the common audience. It is well illustrated that soon after the first studies, in which classical mythology was used to interpret Estonian folklore (e.g. Kreutzwald \& Neus 1854), we meet the socalled maidens of the God of Taara, the daughters of the Meadow Matron, and other such creatures in Estonian folklore.

In fact, the period saw several academic publications in the field of religion (e.g. Schroeder 1906; Amelung 1877; Buch 1897; Holzmeyer 1873; Andersson \& Laakmann 1934) but these did not exert much influence. Possibly one of the reasons for this was that the authors were researchers of Baltic German origin, whose academic discussions of the topic were not so attractive in the popular context. This is why these studies - conducted on a high level, based on the theory and methodology of the period - remained in the background, and in the more general discussions preference was given to the writings of the national ideologists. It was probably a manifestation of a national preference - a young state and a society freed from "700 years of slavery under the rule of the Germans", indeed preferred researchers of Estonian origin to deal with Estonian religion rather than the conquerors and enslavers. This is also well illustrated by the research history, which traditionally starts at the end of the 19th century, together with the folklore collection organised by Jakob Hurt. The earlier, century-old tradition of studying religion by the 
Baltic German enlighteners and romanticists, who prepared the field for academic studies, is either ignored or treated as peculiar attempts but has not fitted into the "real" tradition of studying Estonian religion.

Such a national ideological position formed the basis for the development of the local neo-pagan organisation Taarausulised (followers of Taara religion) in the 1920s-1930s (see the overview in Vakker 2012). The organisation presented itself as a religious community but, based on its statutes and activities, its main purpose was to help to create the image of a "true Estonian". A similar national ideologist trend can also be observed in the works of scholars before World War II. Among academic scholars the two leading figures, Oskar Loorits and Uku Masing, published also studies (in 1932 and 1939 respectively), which had an academic form but a clearly national and ideological content. It is interesting to note the significant difference between popular books and academic research, particularly on the example of Oskar Loorits. In academic studies Loorits followed the scholarly traditions and methods of his time (e.g. Loorits 1935, 1949, 1951a, 1957a, 1960, etc.). Simultaneously, his main principle in popular books (e.g. 1932, 1951b, 1957b) was that the Estonian pre-Christian religion, preserved in contemporary folk tradition, is in essence similar to that of the eastern Finno-Ugric peoples and worshipping of nature is the main characteristic of their culture and worldview. According to Loorits and Masing, these passive and peace-loving peoples were in opposition to aggressive and conquest-oriented Indo-Europeans (especially Germanic tribes, to which historical Slavic tribes were added later on due to the occupation of Estonia by the Soviet Union after World War II). Such ethnic psychological conclusions that were, in many ways, influenced by wishful thinking, were moulded into the form of academic literature, and based on these Masing even entered into heated and principled arguments with his European academic colleagues (Masing 1969).

After World War II, research into Estonian religion came to a standstill. Soviet scientific atheism formally supported studying religion as a backward phenomenon of human culture but in fact it resulted in a few studies about Christianity and the clerical system, whereas the topic of folk religion was entirely ignored. Ironically it 
is reflected in an article by August Annist (1966), which stresses the importance of the study of folk religion for all researchers dealing with the folk culture of the past. But it becomes clear from the same article that the environment for the research of religion was not that favourable, and Annist had to defend himself as well as the study of folk religion in general in his article because the folkloristic and ethnographic study of the animistic spirits got in the way of Soviet scientific atheism. Atheism was the only official scholarly frame to study religion. It mainly focused on the criticism of the Lutheran Church or Christian religion and the clerical system on a wider scale (Remmel \& Friedenthal 2012). Thus, the folk religion remained an unimportant by-subject. Wherever the topic of religion was unavoidable, it was largely based on popular studies by Loorits and Eisen, thus cementing the early 20th-century ideological approach. Single studies about folk religion emphatically stressed the anticlerical essence of the Estonian folk religion (e.g. Raudsep 1961). Even despite the three specialised collections entitled Religiooni ja ateismi ajaloost (About the History of Religion and Atheism, 1956, 1961, 1987), the number of studies specialising in religion remained scarce throughout the Soviet era. In single studies about religion in the more distant past anthropological methods were preferred instead of scientific atheism.

A similar scarcity of relevant studies on religion also continued in the second half of the 20th century. However, a remarkable methodological difference can be followed in the folkloristics of that period - having become more critical of sources, the attitude towards the study of prehistoric religion based on folkloristic material became more sceptical (Viires 1986). Interests shifted from the past-oriented studies to the synchronic study of contemporary religions (Valk \& Kulmar 2015, 189). The period also saw archaeologists' rising interest in religion (e.g. Jaanits 1961; Tamla 1985; Valk 1995, 2001), but all of these remained lone digressions.

Hence, until the beginning of the 21st century, the Estonian history of religion evolved from an initially ideological treatment into a more source-critical and scholarly approach. At the beginning of the 21 st century, however, a new paradigm emerged in addition, where source-criticism and academic theory and methodology again remained in the background. Although unconscious, it exhibits a 
great similarity to the former ideological papers by Loorits and Masing. Somewhat surprisingly this new approach arose outside the academic community, from the contemporary pagan or native religion movement.

\section{Estonian Native Religion and Its Background}

Estonian native religion - Earth belief (Maausk) - (see an overview of the history and beliefs in Västrik 2015) belongs to the broader tradition of European neo-pagan movement, which originates from the middle of the 20th century (Harvey 2010, 358). Paganism encompasses different branches, from the global Wiccans and druids, eco-paganism, etc., to the more local and specific ethnic paganisms, including the Estonian one. According to G. Harvey (2010, 359), nature is the connecting link between these different movements of paganism. The foundation for the emergence of paganism on a Pan-European level was laid by the artists and poets of the 18th and 19th centuries, who found that industrial towns were not worthy living environments and that it was, indeed, the rural areas where one could still find the "awe and majesty of the true cosmos" (ibid). Such an approach encouraged the emergence of neo-pagan movements as well as the preservation and appreciation of preChristian phenomena.

Differently from more general and Western paganisms, like the Wicca or Druid movements, the Eastern European ethnic paganisms establish their concepts based on a nation, traditional folklore, and customs, thus also in a limited geographical area, and generally associate their beliefs with pre-Christian tradition of some particular nation. The dominance of ethnic paganism is well illustrated by the results of the national census conducted in Estonia in 2011. According to this, almost 3000 people identified themselves as members of the Estonian native religion and/or Taara religion, while the Western European neo-pagan movements were represented only by a few people ( 1 druid, 34 Wiccans, 341 pagans, and 272 followers of New Age beliefs - data according to the webpage pub.stat.ee). It also has to be mentioned in this context that during the European poll to study the religiosity of Europeans, where Estonia gained its status as 'the least religious country' in Europe, more than half of 
the population admitted to believe in 'higher forces and spirits' (for more details see Remmel \& Uibu 2015).

The ethnic pagan movements of Central and Eastern Europe are also characterised by the argument that the religion they practise in modern times is the same as the one their ancestors practised in the past, and it has been passed on (as secret knowledge) inside families since ancient times (Harvey 2010, 366). Adrian Ivakhiv (2005) has shown that the idea of religions belonging to a certain area/place and that it is proper to practise these religions in these exact places is more widely spread in the Eastern European pagan movement. Similar views are repeated in several writings by the practitioners of the Estonian native religion as well (e.g. Eller 2000). Such a principle of territoriality differs clearly from Western European neo-pagan movements, which particularly stress the universal nature of pagan religions. Indeed, many arguments of the Estonian native belief are based on Estonian oral tradition but, following the general trend of globalisation, wider neo-pagan and indigenous movements also make a considerable contribution to the modern native religion. A good example of that is the recently developed understanding of the phenomenon of sacred sites. The concept of a sacred place as a natural reservoir was not present in Estonian folklore until recently but has been adopted in contemporary folklore so strongly that it has been taken over without questioning. Controversially, despite the great interest in the sacred places, we still lack comprehensive overviews about the folklore of sacred places. As a personal impression, it can be pointed out that the earliest records from the end of the 19th and beginning of the 20th centuries were mostly connected with fear. Offerings were brought to sacred sites, otherwise something terrible was believed to happen. For the same reason, it was not allowed to touch or remove the offerings brought there to avoid punishment from the spirits of sacred sites. In the first decades of the 21st century, a clear change can be observed, and sacred places are advocated as natural reservations. Such a change is clearly influenced by international indigenous and ecological movements and often legitimised by referring to the International Union for the Conservation of Nature and Natural Resources. As a result of this shift, contemporary deposits are rather brought to sacred places either as a token of gratitude or to increase the power of the place, and the previously dominating motif of 'fear' is missing. 
Vague associations with the past and the principle of territoriality lead to the national approach. Neo-pagan religions in Western Europe have often been associated with nationalism and extreme political views. Eastern European neo-pagan communities have until recently shown relatively little interest in politics. There have, indeed, been active politicians among the practitioners of the Estonian native religion and political lobbying has been carried out, but the latter has been restricted to the placement of sacred sites under national protection. In recent years, Maavalla Koda (the Estonian House of Taara and Native Religions) has achieved significant political support (Ringvee 2015), which is most clearly manifested in the establishment of a support group of sacred places in the Estonian Parliament in 2012. In a more general ideology, the nationalism related to Estonians has an important position among the practitioners of the native religion. With reference to the Estonian native religion, attempts have been made to create an image that native faith is the traditional religion in Estonia, and that it should also form a part of the cognition of ethnicity (e.g. Kaasik 2007). As the Estonian native religion is not considered to be a religion, but a worldview and a way of life, such claims could be treated on a wider basis. Hence, it has been claimed that everyone who practises the rituals adopted by the practitioners of the Earth believers (such as Christmas and Midsummer) is unconsciously a practitioner of the same religion. In doing so, it has been presumed by default that Christmas and Midsummer are, indeed, Estonian holidays with a pre-Christian background. Such views are published widely in newspaper articles in the declarative mood by the practitioners of the native faith, making the ordinary reader accept that these beliefs derive directly from the pre-Christian past.

The Earth believers' movement remained a small niche community during the $1990 \mathrm{~s}$, popularising folk religion and folk customs. The rise of the movement started in the first decade of the 21st century, in connection with major developments and the construction boom as well as the privatisation of properties, which thus changed the status or threatened the existence of natural sacred places. Such cases afforded public attention, which resulted in the growing importance of the convictions of this movement. The first example of the kind was Samma holy grove in the north of Estonia, which the landowner wanted to sell in 2001. As it was a restored sacred grove 
and one of the most significant and important gathering places for the followers of the native faith, a proposal was made to register the property as municipal land. One of the arguments given in favour of doing so was that of the freedom of religion and protection of human rights which have, from then onwards, been presented in most of the disputed cases. Arising from the principle that a sacred site is holy in itself, not created by human beings, humans must not destroy a sacred site and should do everything to protect it. Moreover, even if a sacred site is not in active use, then in order to guarantee the freedom of religion, the practitioners of native religion must be able to carry out their rituals in any sacred site in Estonia. Religious events may also be potential, meaning that for the application of the requirement of religious freedom rituals do not have to be carried out at the site time and again, but a respective possibility must be ensured. Such conduct manifested itself vividly in the following cases of Kunda, Paluküla, Panga, Purtse, etc. During these campaigns another important principle arose: the sacred sites constitute the cultural heritage of ancient Estonians and "our ancestors", and the state is tasked with their protection. The latter is usually confirmed also by the reference from the Estonian constitution, which states as the main purpose of the Republic of Estonia to guarantee and preserve the cultural heritage of Estonia, and according to the discourse of native believers sacred places are undoubtedly part of it.

In summary, the Estonian native religion is, on the one hand, indeed understood as a neo-pagan religion, but on the other hand, native religion has acquired the meaning of cultural heritage and cultural identity, and hence native religion and the related phenomena (such as sacred natural sites) are also valued by people who do not practise the religion themselves and do not share such values. It is difficult to criticise cultural heritage from the point of view of national identity, and this is probably one of the reasons why the native religion approach has so strongly and without any criticism spread outside the neo-pagan movement itself. 


\section{Balancing on the Edge: Pagan Ideology Becoming Part of Academic World}

As was mentioned at the beginning of the article, Estonian religion has attracted little attention among academic scholars due to the synergy of several different factors and, in the little attention it has deserved, national and ideological treatments have turned out to be more popular. During the rise of importance of the Earth believers' movement in the past decades, their publication activity increased significantly. In particular, alongside a wider spread of public and free-of-charge web communication, the movement has found a medium that enables them to exert easy and rapid influence. Particularly journals and newspapers related to nature and the environment (Eesti Loodus, Maaleht, etc.) became eager to publish these articles. Regular overviews of sacred sites and folk customs followed therein, and more general articles about the movement of Estonian native religions and holidays were published. Most importantly, these overviews also cover the rules on how to behave in sacred places, and as these are related with nature protection and sustainable behaviour, such articles do not look like religious, but rather like cultural and environmental ones. Also the style how arguments are represented rather resembles popular scientific articles and not religious texts. Thus, the conventional reader is seemingly presented the results of academic research, although the content of these articles derives from contemporary paganism.

The establishment of the Centre of Sacred Natural Sites at the University of Tartu took the activities of the practitioners of native religion to a completely new level: unlike other neo-pagan movements in Europe, the Estonian example has achieved a far more significant influence and position in society (Ringvee 2015). As the Centre is part of the University of Tartu, the pagan worldview is presented as an academic approach to the Estonian folk culture. Such an approach was introduced a few years earlier as a result of the organisation of a conference on sacred sites and publication of a collection of articles, in which scholarly and Earth believers' approaches were mixed (Valk \& Kaasik 2007). Several courses are organised at the University of Tartu and the Estonian University of Life Sciences about sacred sites, with the aim to introduce sources and traditional customs related to these places. The entwinement 
of scholarly and religious approaches is evident in the courses, and it seems that academic participation is partly used for legitimising the religious approach. As the main task of the Centre was supposed to be coordination of the project to locate, map, and prepare sacred sites to be taken under state protection, the Centre also started close cooperation with the National Heritage Board. Thus, after gaining an official position in the academic and administrative structures, the status of the pagan community increased, legitimised by official institutions.

\section{Mingling Pagan and Academic: Some Recent Approaches in Studying Estonian Religion}

Proceeding from the earlier tradition of a direct approach to oral tradition as a historical source, a similar uncritical view to interpret oral narratives as reflecting real history has been held in the past decade. Borrowing a metaphor from another discussion (see Tamm 2013), folklore has been taken as "yesterday's newspapers", where oral stories are interpreted literally, without considering basic source criticism or any theoretical background. Partly it has been influenced by the traditional approach in which folklore dominates over all other types of sources in the studies of religion or intangible subjects. Although the style is most strikingly represented by the practitioners of native religion (e.g. Kaasik 2007; Kütt 2007), a similar approach sometimes also appears among researchers with an academic background. Emphasising of pure oral tradition as a primary source, without any critical discussion, is noticeable mainly in disciplines outside folkloristics, and sometimes even inside folkloristics itself. As a combination, it has created an amorphous approach, in which academic form is used for suggesting religious convictions. I will attempt to summarise the main characteristics of this style of research.

A simplistic treatment of sources has led to the approach in which oral sources are taken to represent a "history" that is true and real and that has, despite the fact that it has not yet been recorded in chronicles, been steadily passed on by local inhabitants for centuries. This approach pays little attention to the international motifs represented in oral tradition, folk etymology of toponyms or historical events, such as extensive famines, wars, and plagues, which 
decreased the population extensively. Even if these circumstances have been taken into account, folklore has still been considered a former custom that might have been lost to a great extent; yet, by finding the "right" fragments from oral tradition, it is possible to restore the wider picture. Such a modest attention to historical events interestingly corresponds with Oskar Loorits' studies almost a century before. Loorits also dated the origin of most of the folk religion phenomena to the pre-Christian past, and at the same time largely ignored Middle and Modern Age processes. Such a treatment of sources is particularly characteristic of the analysis of behavioural norms established for sacred sites during recent years. By taking the constantly evolving and reinterpreted oral tradition to be a source of information, attempts are made to draft behavioural guidelines to be followed at sacred sites as stated rules (Kütt 2007). These have been presented to be applied more or less universally both in time and space, leaving an impression as if traditions at Estonian sacred sites were organised according to institutional religious norms.

The sustained treatment of folklore also ties in with the vision of the history of Estonians as something of great stability. As expected, such (ab)use of the concept of time often appears in folkloristic studies or theology but surprisingly often occurs also in history and archaeology. Presuming that until the end of the 19th century (and based on contemporary authors and ideologies also in the 20th century) the population of Estonia was rural and agrarian, it is considered to be a coherent link to modern and medieval societies, in some cases dating back to the beginning of the agrarian society or even all the way to the first inhabitants. Based on such seeming continuity of economic and social systems, it has been provided that also the mental world and religion have been continuous. Indeed, some changes or developments are accepted, but as the essence of religion is linked, on the one hand, to the rural society and, on the other hand, to the genetics of the local people, unreasonably stable treatments of religion are easily created. This ties in with the reasoning for the collection of oral folklore that has emerged in recent years: as demographic migration, manifesting itself in the draining of rural areas of inhabitants, can be monitored once again, the collection of folklore would be justified before "the last carriers of folk tradition disappear". Ironically this justification was already used 
by the first scholars of Estonian history and from then onwards by almost all scholars over the course of three centuries. For instance, the last Baltic chronicler Christian Kelch used similar references to old customs that were not in use at the time of writing the chronicle in 1688-1691 (Kelch 2004, 28). Hence, folklore has not disappeared anywhere in the course of time and it will not do so because it is a living cultural phenomenon that persists and develops along with the living society. Examples that seemingly confirm the disappearance of folk tradition and occur in stereotyped formats - "we no longer know, but my grandmother knew...", etc. - should be seen as typical truth-constructing mechanisms, in which information of vague origin is legitimised with a reference to the authorities in the past. Naturally, it does not mean that older phenomena are missing in oral tradition, but rather that the meaning of oral stories comes first and foremost from the time of recording, and the application of such references further into the distant past without reasonable argumentations is not justified.

Attempts have been made to confirm the longevity of oral traditions by creating a link between recorded folklore and archaeological sources. Accordingly, the collecting of folklore began at the end of the 19th century, but as it was collected from older people, it seemingly reflects the situation at the beginning of the 19th century. As the period covered by archaeological studies in Estonia ends with the 18th century, it has been claimed that this makes it possible to find a link between archaeology and oral sources separated from one another only by a century (Valk 2006, 311). Such a clearly artificial construct does not, however, justify in any way the significant age of folklore - and even more so when there are several phenomena in archaeological material the occurrence of which is documented until the beginning of the 19th century, but which are almost never reflected in oral tradition. One example could be the coin offerings in churches (Johanson \& Jonuks 2015) which, based on the dating information, belong to the period from the Middle Ages to the first decades of the 19th century, after which the depositing of coins in churches ceased. However, coin deposits are not reflected in oral tradition, except in a single example, despite the relatively recent practice. This is just one example that can be compared in different sources and which suggests that folklore should be studied and 
understood exclusively in its own chronological and spatial context, and further conclusions could be made only after that.

Simultaneously with continuity, another and even more recent tradition stresses the difference of Estonian beliefs and customs from those of the rest of Europe. Partly it is related to the widely popular thesis that Estonia is principally a stable place where old beliefs and customs have been sustained for a very long time. The thesis was founded already by the ideological books written by Loorits in the 1930s. In the current tradition Estonia is advertised as the only place in Europe where sacred natural sites have been preserved because elsewhere in Europe they were destroyed and forgotten long ago due to Christianisation (Kaasik 2007, 32; Valk 2007, 137). Traditional sacred sites are certainly not a cultural phenomenon attributable only to Estonia. They have been discussed in great numbers and with colourful descriptions elsewhere in European literature, especially in the 19th century folklore publications (e.g. Hope 1893; Magni 1901). References have been made to offerings and specific sacrificial finds on stones, in springs, around trees, etc. Unlike in Estonia and Eastern Europe, such strong public interest towards the former sacred sites has not been witnessed in Western Europe during the past few decades. Some attention is paid to sacred sites by the representatives of the contemporary neo-pagan religions (e.g. Wallis 2003, $142 \mathrm{ff}$.), but they concentrate more on archaeological sacred sites rather than folkloristic places. However, studying of the recent depositions and combining of archaeology and oral tradition seems to be a rising field (e.g. Hooke 2010; Houlbrooke 2015). It is probably due to the differences arising from the source material and research traditions that Estonian sacred sites seem so different and unique.

In addition to the uncritical approach to sources, the research style characteristic of the Estonian native religion is also described by the preference given to emotionality over reasoning. Emotionality in this context is expressed first and foremost as related to national identity and being an Estonian, and the treatment of the religion of the past and sacred sites as national cultural heritage. Such a starting point makes the whole approach hard to criticise. A similar situation could be seen in the 1930s when Loorits' source publications and earlier ideologists' concepts about Estonian religion were 
indeed known and spread among people, but were not discussed in academic circles; although they were selectively adopted, there was no criticism as regards obvious misinterpretations and fantasies. One of the reasons was probably again the association of religion with national identity, and in such a small national society as Estonia, it was difficult to criticise ethnic markers or cultural heritage objects. Simultaneously, the low number of scholars studying religion does not enable advanced academic discussion.

\section{Conclusion}

What seems to characterise studies into Estonian religions throughout the scholarly history is the relatively low interest shown by the academic scholars. This has enabled some single authors to become dominant and shape the whole research tradition. As religion did not become a specific topic during the 20th century, Oskar Loorits' methodologically disputable approach dominated all over the field. Besides the lack of academic discussion, another problematic development is a tight connection between folk religion and the Estonian nation. Christianity and church history have often been seen as parallel systems, characteristic of towns and upper classes. Estonian Middle and Modern Age rural society, on the other hand, is seen as following folk religion, which is comprised of pre-Christian beliefs and single Christian effects. Thus folk religion is associated with the Estonian nation. It has become more evident in the past few decades when the contemporary pagan movement Maavalla Koda has advertised their belief system as something essential to Estonians. This has resulted in understanding Maausk or native belief as cultural heritage, which is shared and accepted also by people who are not members of this community. Such a powerful and emotional approach from the contemporary pagan side and the lack of academic studies have created a situation in which the pagan view is understood as an academic approach and it is not criticised. This has formed a grey zone, in which views of a religious group are published in semi-academic style and authors make it difficult for a common reader to understand the border between scholarly and religious statements. The latter should not be understood as being against the popular style of scholarly writings but the difference between the academic and religious approach should be clearer for 
the common reader. The situation has also been blurred by several uncritical studies about the oral tradition. These do offer attractive examples, allowing far-fetched interpretations, yet ignore the very basic of the academic style - to be critical about the source material. Direct interpretations of folk etymologies, ungrounded dating of oral tradition motifs, and wishful thinking do support the idea of Estonia being unique; the idea is easily accepted among the common audience but it has little to do with academic tradition.

The popularity of this "grey zone" is also well understandable in the Estonian context - as the contemporary native religion has been advocated as cultural heritage, it is easier for a common reader to accept this than scholarly studies, which hardly state anything so explicitly. Furthermore, due to the existing and influential framework, the scholarly approach has either to accept (partly) the modern pagan view or has to argue against it, which can hardly be a constructive way. And altogether it supports the situation where little academic alternative exists to the contemporary pagan views. Indeed, academic scholars have studied and published articles about religion in Estonia in the past, about contemporary paganism (e.g. Västrik 2015) or different spiritual movements (e.g. Uibu 2016). As most of these have been published in academic journals and often in a foreign language, such studies cannot be used as an alternative to the grey zone studies.

Emphasising the cognition of ethnicity is still one of the main topics. By claiming to be the bearer of the continuity of historic Estonian faith on the one hand and the guard of intangible cultural heritage on the other, the native belief movement achieved such an important position in society that outside of it, among ordinary people, the native religion is considered a continuous religion with a beginning that precedes the conquests of the 13th century. And hence, ironically, the neo-pagan religious group has become very influential in a state that is publicly advertised as the most secular state in the world.

\section{Acknowledgments}

The author of the article is particularly grateful to Ergo-Hart Västrik and Atko-Sulhan Remmel for their valuable comments to the earlier draft of 
the article. Writing of this paper has been supported by the institutional research grant IUT 22-5 and the European Union through the European Regional Development Fund (Centre of Excellence in Estonian Studies).

\section{References}

Amelung, Friedrich 1877. Über den volkstümlichen estnischen Aberglauben und den estnischen Antonius-Cultus. Dorpat: C. Mattiesen.

Andersson, Walter \& Laakmann Heinrich 1934. Ein neues Dokument über den estnischen Metsik-Kultus aus den Jahre 1680. Acta et Commentationes Universitatis Tartuensis (Dorpatensis), 32 (5). Tartu.

Annist, August 1966. Eesti rahvausundi uurimise olukorrast. Keel ja Kirjandus, 8, pp. 457-467.

Buch, Maximilian Theodor 1897. Ueber den Tõnnis-cultus und andere Opfergebräuche der Esthen. Vorgetragen in den sitzungen der Gesellschaft den 18 jan. u. 15 febr. 1896. Helsingfors: Finnischen Litteratur-Gesellscaft, pp. $1-8$.

Eisen, Matthias Johann 1918. Eesti muistsed jumalad ja wägimehed. Tartu: G. Roht.

Eisen, Matthias Johann 1926. Eesti muistne usund. Tartu: Postimees.

Eller, Kalle 2000. Omauskudest tänapäeva maailmas.

http://www.maavald.ee/koda/jumioie-jutud/29-noatera-jutt

Harvey, Graham 2010. Contemporary Paganism: Listening people, Speaking Earth. New York: New York University Press.

Heraklides, A. [Aleksander Treimann]1908. Eesti usk. Tallinn: Mõte.

Herder Johann Gottfried 1773. Auszug aus einem Briefwechsel über Ossian und die Lieder alter Völker.

http://www.uni-due.de/lyriktheorie/texte/1773_herder.html (2.03.2017).

Holzmeyer Jean Baptiste 1873. Osiliana. Erinnerungen aus dem heidnischen Göttercultus und alte Gebräucheverschiedener Art, gesammelt under den Insel Esten. Vehandlungen der Gelehrten Estnischen Gesellschaft, 7 (2). Tartu

Hope, Robert Charles 1893. The legendary Lore of the Holy Wells of England, including Rivers, Lakes, fountains and Springs. London: Elliot Stock. 
Hooke, Della 2010. Trees in Anglo-Saxon England: Literature, Lore and Landscape. Woodbridge: Boydell.

Houlbrooke, C. 2015. Small change: Economics and the coin-tree in Britain and Ireland. Post-Medieval Archaeology, 49 (1), pp. 114-130.

Hupel, August Wilhelm 1774. Topographische Nachrichten von Lief- und Ehstland, I. Gesammelt und herausgegeben durch August Wilhelm Hupel. Riga: Johann Friedrich Hartknoch.

Ivakhiv, Adrian 2005. In search of Deeper Identities. Neopaganism and "Native faith" in Contemporary Ukraine. Nova Religio, 3, pp. 7-38.

Jaanits, Lembit 1961. Jooni kiviaja uskumustest. E. Jansen (ed.). Religiooni ja ateismi ajaloost Eestis. Artiklite kogumik II. Tallinn: Eesti Riiklik Kirjastus, pp. 5-70.

Jakobson, Carl Robert 1870. Kolm isamaa kõnet. St Peterburg: E. Pratz.

Johanson, Kristiina \& Jonuks, Tõnno 2015. Superstition in the House of God? Some Estonian Case Studies of Vernacular Practices. Mirator, 16 (1), pp. 118-140.

Kaasik, Ahto 2007. Ajaloolised looduslikud pühapaigad - väärtused looduse ja kultuuri piirimail. Valk, H. \& Kaasik, A. (eds.). Looduslikud pühapaigad. Väärtused ja kaitse. Õpetatud Eesti Seltsi Toimetised, 36. Tartu: Tartu Ülikool, Õpetatud Eesti Selts, pp. 23-74.

Kelch, C. 2004. Liivimaa ajalugu. Tõlkinud ja eessõna Ivar Leimus. Tartu: Eesti Ajalooarhiiv.

Kreutzwald, Friedrich Reinhold \& Neus, Hans 1975 [1854]. Mythische und magische Lieder der Ehsten. Gesammelt und herausgegeben von Fr. Kreutzwald und H. Neus. St Petersburg: Buchdrukerei der Kaiserlichen Akademie der Wissenschaften. Nachdruck 1975. Verlag Harro v. Hirschheydt Hannover-Döhren.

Kütt, Auli 2007. Maarahva pühade puude ja puistutega seotud käitumisnormid. Valk, H. \& Kaasik, A. (eds.). Looduslikud pühapaigad. Väärtused ja kaitse. Tartu. Õpetatud Eesti Seltsi Toimetised, 36, pp. 185-212.

Lang, Valter 2006. The History of Archaeological Research (up to the late 1980s). Lang, V. \& Laneman, M (eds.). Archaeological research in Estonia 1865-2005. Estonian Archaeology, I. Tartu: Tartu University Press, Humaniora: archaeologica, pp. 13-40.

Loorits, Oskar 1932. Eesti rahvausundi maailmavaade. Tartu: Eesti Kirjanduse Selts. 
Loorits, Oskar 1934. Kujutelmade ja motiivistiku päritolust ja vanadusest. Eesti Rahva Muuseumi Aastaraamat, IX-X. Tartu: Sihtasutis "Eesti rahva muuseum", pp. 165-175.

Loorits, Oskar 1935. Mulgimaa ohvrikohad. Die Opferstätten in Mulgimaa. Kaleviste mailt. Tartu: Ôpetatud Eesti Selts, pp. 226-319.

Loorits, Oskar 1949. Grundzüge des Estnischen Volksglaubens, 1. Skrifter utgivna av Kungl. Gustav Adolfs Akademien för folklivsforskning, 18 (1). Lund: Carl Blom.

Loorits, Oskar 1951a. Grundzüge des Estnischen Volksglaubens, 2. Skrifter utgivna av Kungl. Gustav Adolfs Akademien för folklivsforskning, 18 (2). Lund: Carl Blom.

Loorits, Oskar 1951b. Eestluse elujõud. Stockholm: Tõrvik.

Loorits, Oskar 1957a. Grundzüge des Estnischen Volksglaubens, 3 (1). Skrifter utgivna av Kungl. Gustav Adolfs Akademien för folklivsforskning 18 (3:1). Lund: Carl Blom.

Loorits, Oskar 1957b. Eesti hõimu olemusest. Minu varamu. Koguteos noortele Eesti kultuuritegelastelt. Toronto: Eesti gaidid paguluses.

Loorits, Oskar 1960. Grundzüge des Estnischen Volksglaubens, 3 (2). Skrifter utgivna av Kungl. Gustav Adolfs Akademien för folklivsforskning, 18 (3:2). Lund: Carl Blom.

Luiga, Juhan 1995 [1908]. Eesti muinasusk. Mäss ja meelehaigus. Tartu: Ilmamaa, pp. 194-201.

Magni. Antonio 1901. Pietre cuppelliformi nuovamente scoperte nei dintorni di Como. Rivista archeologica della provincial di Como.

Masing, Uku 1939. Taara päritolust. Usuteadusline ajakiri, 1, pp. 1-16.

Masing, Uku 1969. C. Scott Littleton. The New Comparative Mythology: an anthropological assessment of the theories of Georges Dumézil. Reviw article. Semiotica, 1 (3), pp. 339-355.

Merkel, Garlieb Helwig 1798. Die Vorzeit Lieflands: ein Denkmal des Pfaffen- und Rittergeistes, I. Berlin: Voss.

Moora, Harri 1924. Eestlaste, liivlaste ja lätlaste vaatest ristiusule nende kristianiseerimise algul. Ajalooline Ajakiri, pp. 81-90.

Peterson, Kristjan Jaak 1822. Christfrid Ganander's Thomasson's Philos. Mag. Finnische Mythologie. Aus dem Schwedishen übersetzt, völlig umbearbeitet und mit Anmerkungen versehen von Christian Jaak Peterson, 
Literat in Riga. Beiträge zur genauern Kenntniss der ehstnischen Sprache. 14 heft. Pernau: Reval bei Bornwasser, pp. 2-114.

Raudsep, Loreida 1961. Eesti rahvaluulekogudes leiduvad meieisapalve paroodiad. Keele ja Kirjanduse Instituudi uurimused, VI. Tallinn: Eesti Riiklik Kirjastus, pp. 141-153.

Reiman, Villem 1901. Eesti muinasusk. Kõne. Jurjev: Postimees.

Religiooni ja ateismi ajaloost Eestis, I. 1956. Ed. E. Jansen. Eesti NSV Teaduste Akadeemia Ajaloo Instituut. Tallinn: Eesti Riiklik Kirjastus.

Religiooni ja ateismi ajaloost Eestis, II. 1961. Ed. E. Jansen. Eesti NSV Teaduste Akadeemia Ajaloo Instituut. Tallinn: Eesti Riiklik Kirjastus.

Religiooni ja ateismi ajaloost Eestis, III. 1987. Ed. J. Kivimäe. Eesti NSV Teaduste Akadeemia Ajaloo Instituut. Tallinn: Eesti Riiklik Kirjastus.

Remmel, Atko-Sulhan \& Friedenthal, Meelis 2012. Religiooni ja ateismi ajaloost Eestis. Ajalooline ajakiri, 141/142, pp. 203-220.

Remmel, Atko-Sulhan \& Uibu, Marko 2015. Outside Conventional Forms: Religion and Non-Religion in Estonia. Religion and Society in Central and Eastern Europe, 1, pp. 5-20.

Ringvee, Ringo 2015. Funding Religious heritage in Estonia: From sacred Buildings to Sacred Groves. A. Fornerod (ed.). Funding Religious Heritage. Farnham: Ashgate Publishing, pp. 113-125.

Schroeder, L. v 1906. Germanische Elben und Götter: beim Estenvolke. Sitzungsberichte der Kaiserlichen Akademie der Wissenschaften in Wien. Philosophisch-Historische Klasse, 153 (1). Wien: Hölder.

Tamla, Toomas 1985. Kultuslikud allikad Eestis. Tedre, Ülo (ed.). Rahvasuust kirjapanekuni: Uurimusi rahvaluule ja proosaloomingu kogumisloost. Emakeele Seltsi toimetised, 17. Tallinn: Eesti NSV Teaduste Akadeemia, pp. $122-146$.

Tamm, Marek 2013. Vahtre loeb Henriku kroonikat kui üle-eilset ajalehte. Postimees (5.02.2013).

http://arvamus.postimees.ee/1128058/marek-tamm-vahtre-loeb-henrikukroonikat-kui-uleeilset-ajalehte

Uibu, Marko 2016. Re-emerging religiosity: the mainstreaming of new spirituality in Estonia. Journal of Baltic Studies, 47 (2), pp. 257-274. 
Vakker, Triin 2012. Rahvusliku religiooni koostamise katsed - Taara usk. Mäetagused, 50, pp. 175-198.

https://dx.doi.org/10.7592/MT2012.50.vakker

Valk, Heikki 1995. Lõuna-Eesti XIII-XVII/XVIII sajandi külakalmistud rahvatraditsioonis ja uskumustes. Hiiemäe, Mall \& Kõiva, Mare (eds.). Rahvausund tänapäeval. Tartu: Eesti TA Eesti Keele Instituut \& Eesti TA Eesti Kirjandusmuuseum, pp. 454-471. http://www.folklore.ee/rl/pubte/ee/usund/eesti/valkh.pdf

Valk, Heikki 2001. Rural cemetries of southern Estonia 1225-1800 AD. CCC papers, 3. Visby: Gotland University College \& Centre for Baltic Studies \& Tartu: University of Tartu, Archaeology Centre.

Valk, Heikki 2006. Archaeology, Oral Tradition and traditional Culture. Lang, V. \& Laneman, M (eds.). Archaeological Research in Estonia 18652005. Estonian Archaeology, 1. Tartu: Tartu University Press, pp. 311-316.

Valk, Heikki 2007. Looduslikud pühapaigad kui muistised: arheoloogia vaatenurk. Valk, H. \& Kaasik, A. (eds.). Looduslikud pühapaigad. Väärtused ja kaitse. Tartu: Õpetatud Eesti Seltsi Toimetised, 36, pp. 135-170.

Valk, Heikki \& Kaasik, Ahto (eds.) 2007. Looduslikud pühapaigad. Väärtused ja kaitse. Tartu. Õpetatud Eesti Seltsi Toimetised 36.

Valk, Ülo \& Kulmar, Tarmo 2015. Estonian study of religion: A historical outline of the 20th century developments. T. Bubik \& H. Hoffmann (eds.). Studying Religions with the Iron Curtain Closed and Open. The Academic Study of Religion in Eastern Europe. Numen Book Series: Studies in the History of Religions. Leiden, Boston: Brill Academic Publishers, pp. 166-198.

Viires, Ants 1986. Paar pilguheitekatset eesti muinasusku. Looming, 12, pp. 1666-1675.

Västrik, Ergo-Hart 2015. In search of genuine religion: the contemporary Estonian maausulised movement and national discourse. K. Rountree (ed.). Pagan and Native Faith Movements in Europe: Colonialist and Nationalist Impulses. New York, Oxford: Berghahn, pp. 130-153.

Wallis, Robert J. 2003. Shamans/Neo-Shamans: Ecstasies, Alternative Archaeologies and Contemporary Pagans. London: Routledge. 


\section{ELM Scholarly Press \\ SATOR 18}

http://dx.doi.org/10.7592/Sator.2017.18

\section{BALKAN AND BALTiCUM}

Current Studies in the Postsocialist Space

Edited by

Ekaterina Anastasova and Mare Kõiva

Tartu 2017 
Editors and compilers: Ekaterina Anastasova, Mare Kõiva Series "Sator" editor: Mare Kõiva

Language editors: Liisa Vesik, Lii Liin

Cover photo: Jaak Kikas, 2017 "Autumn in Tartu"

International committee

Tiiu Jaago (Tartu University); Reet Hiiemäe (Estonian Literary Museum); Mare Kalda (Estonian Literary Museum); Tarmo Kulmar (Tartu University); Nikolay Kuznetsov (Estonian Literary Museum); Aado Lintrop (Estonian Literary Museum); Emily Lyle (School of Scottish Studies in Edinburgh); Mirjam Mencej (Ljubljana University); Jonathan Roper (Tartu University); Marju Kõivupuu (Tallinn University); Ülo Valk (Tartu University); Tatjana Vladõkina (Institute of Udmurtian History, Language and Literarture, Izhkar); Irina Vinokurova (Institute of Karelian History, Language and Literarture in Petroskoi); Ergo-Hart Västrik (Tartu University)

Supported by Estonian Academy of Sciences, Bulgarian Academy of Sciences, the Centre of Excellence in Estonian Studies (CEES, European Regional Development Fund) and is related to research projects IRG 22-5 (Estonian Research Council).

\section{$\boldsymbol{C} E \mathbf{E} \times \begin{aligned} & \text { Centre of excellence } \\ & \text { in Estonian Studies }\end{aligned}$}

Series "Sator. Artikleid usundi- ja kombeloost", 18 http://www.folklore.ee/rl/pubte/ee/sator/sator18/

ISSN 1736-0323 (online)

ISBN 978-9949-586-58-5 (printed)

ISBN 978-9949-586-61-5 (online) ISSN 1406-2011 (printed)

DOI: 10.7592/Sator.2017.18

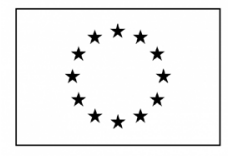

European Union European Regional Development Fund

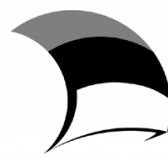

Investing in your future

\section{EUROPEAN UNION}

Regional Development Fund

Investing in your future
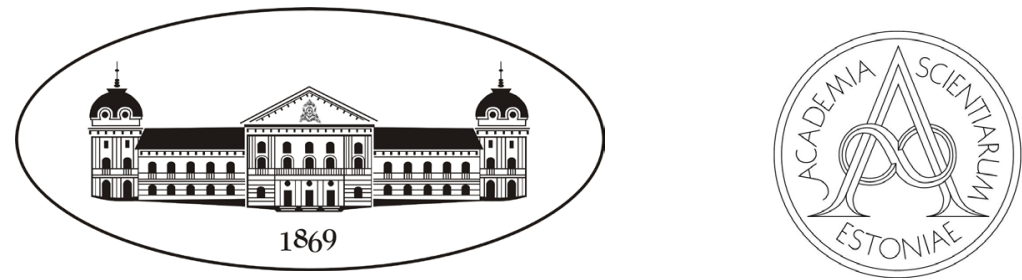


\section{Contents}

Preface

Mare Kõiva, Ekaterina Anastasova

CONSTRUCTING IDENTITY AND SOCIAL TIES

Ethnographic Studies on the Montenegrin

Festive Costume as a National Symbol

Sofiya Zahova

Social Ties of Bulgarians and Rudari in the Mediterranean Countries

Magdalena Slavkova

\section{RECASTING RELIGION AND \\ RELIGIOUS IDENTITY}

Contemporary Development of the Akyazili

Baba Tekke / St. Athanasius in Bulgaria

Yelis Erolova

Turkish Religious Identity in Bulgaria

94

in the Last Twenty-Four Years (1989-2013)

Mila Maeva

The Feast of Cyril and Methodius in Bessarabia and Crimea, Ukraine

Ekaterina Anastasova 
The Saints of Death in the Traditions

of the Balkan People

Rachko Popov

\section{CONSTRUCTING NEW SPIRITUALITY}

New Trends in the Study of Religion in Estonia -

Contemplations in the Grey Zone between

Religion and Science

Tõnno Jonuks

Constructing New Spirituality in Modernity -

the Case of the White Brotherhood in Bulgaria

Svetoslava Toncheva

Constructing Contemporary Periodical and

Occasional Rituals

Mare Kõiva

The Making of a Sacred Place:

221

An Example of Constructing Place Identity in the Contemporary Mentality

Reet Hiiemäe

\section{CHANGING TRADITIONS}

Bridge Over the Rainbow. Animal Burials and

Animal Cemeteries in Post-Socialist Estonia

Marju Kõivupuu

Simple Hide-and-seek at its Core: Play Features and the Game of Geocaching

Mare Kalda 